\title{
Indirect Speech Acts
}

\author{
Between Modern Linguistics and Arabic Linguistic Tradition
}

Hisham I. Abdulla Khalifa

Asst. Prof - Iraqi University

\begin{abstract}
The present paper is part of a larger piece of work intended to challenge the long-standing assumption that speech acts, as linguistic phenomena, were first discovered by modern language philosophers in the middle of the twentieth century; it is a commonplace assumption in modern linguistic literature that language philosophers like John Austin , Ludwig Wittgenstein were the first to propose the theory, and that the following generation of philosophers like John Searle and J. Sadock added very important developments to it such as the notion of indirect speech acts (ISAs) .
\end{abstract}

The researcher's aim in this paper is to question the above assumption about the discovery of the phenomenon of indirect speech acts, and to trace it back to Arab linguists. Thus the problem or the question that the present paper sets out to answer is whether the phenomenon has a longer history than is claimed in the literature, and whether Arab linguists were well acquainted with it .

The first part of the paper is a brief account of the notion of ISAs as it appears in modern linguistic literature in the west with special reference to the often quoted samples of questions used for forces other than seeking information. The focus is narrowed on two approaches to explaining the phenomena, namely, the idiom or ambiguity approach proposed by generative semanticists like Sadock(1974) and the inferential approach adopted by Searle (1975). Both approaches subscribe to the literal force hypothesis (LFH), but they part company when it comes to the nature of the explanation they offer. According to Sadock, ISAs are idioms and there is ambiguity in their literal senses, whereas Searle argues that ISAs are speech acts performed indirectly (and simultaneously) through the performance of other speech acts, and that the additional indirect force is acquired by virtue of a pragmatic inference and with the help of an inference trigger and a series of inferential steps. The controversy between the two approaches sometimes boils down to a single important question which is the source of the heated debate, i.e., " Does an utterance lose or retain its literal force when used as an ISA ?". A third approach to ISAs is a radical pragmatic solution; it rejects the (LFH) in principle and denies the existence of literal force and consequently cancels the problem of ISAs.

The second part of the paper deals with the Arabs' contribution to the theory, comparing their findings with those of modern linguists of the west. The method adopted by the researcher is using quotations from the books of traditional Arab and Muslim linguists such as rhetoricians and jurisprudents in an attempt to investigate his hypothesis that Arab and Muslim linguists were well acquainted with the concept of ISAs. Using these quotations, he sets out to trace the main features of the theory of ISAs back to Arab and Muslim linguists who showed unprecedented understanding 
of the main tenets of the theory. Here, too, following the literature, the focus is narrowed on questions as a sample of ISAs.

\section{PART I}

\section{Indirect Speech Acts (ISAs) in Modern Linguistics}

The notion of ISA is based on the literal force hypothesis (LFH), the assumption that illocutionary force is built into sentence form, that generally there is a form-force correlation, or to be specific, there is a correspondence between the imperative, interrogative and declarative sentence-types on the one hand, and the illocutionary forces generally associated with them (requesting, questioning and stating), on the other, with the exception of explicit performatives, which are declarative in form and have their force named by the performative verb in the highest clause ${ }^{1}$.

Thus any mismatch between form and force or any violation of the LFH, is an exception that needs explanation. The standard account is that the sentence does have its literal force according to LFH, but has, in addition, an indirect force. Hence any utterance that violates LFH is an indirect speech act (ISA). But on this view most utterances are indirect. The problem of ISAs is closely related to the issue of the classification of implicit performatives. Searle (1975) concentrates on directives because in them there is a strong motivation for indirectness, i.e. politeness:

(1) - Can you pass the salt?

- Would you pass the salt?

Two approaches have been proposed to deal with this phenomenon: the idiom theory and the inferential theory. According to the idiom theory, sentences like those in (1) are in fact idioms for, and primary or implicit performative versions of "I hereby request you to pass the salt ". In other words, sentences of the form " Can you VP? " are idioms for "I request you to VP ". Sadock (1974) argues that these forms should not be broken down because their meaning is not compositional, but they should be treated as unanalyzed wholes with the equivalent semantic meanings. In this respect they are like "kick the bucket" in the sense of "die". Sadock provides us with some lexical and syntactic support for his idiom theory, but it

\footnotetext{
${ }^{1}$ However, some speech- act theorists, Bach \&Harnish (B\&H), for example, argue that explicit performatives are no exception. See (Bach \&Harnish ,1979) for their view of performatives as ISAs.
} 
suffers from some problems. To mention but a few, firstly, the addressee can respond to both the surface form and the alleged underlying idiomatic force as in (2)

(2) a - Can you pass the salt?

b- Sure. (addressee passes the salt).

Secondly, idiom theory suggests that forms like the one in (2a) are ambiguous and this creates the need for a pragmatic inferential theory to disambiguate the forces.

Inference theories of ISAs have more explanatory power. According to them sentences of the form "Can you VP?" retain the literal force of a question; and they, in addition, acquire the indirect force of a request, by virtue of a pragmatic inference.

Levinson (1983:270) points out that 'one can think of the additional indirect force as, variously, a perlocution, a Gricean implicature, or an additional conventionally specified illocution'. Therefore there are more than one inference theory, but they share some essential properties such as subscribing to LFH and the existence of an "inference trigger" which indicates that the literal force or meaning is not feasible in the context and must be 'repaired' by some inference using specific principles or rules.

Searle's (1975) is the most widely accepted version of an inference theory. He integrates his speech act theory into Grice's (1975) theory of implicature, which is a general theory of pragmatic inference. Thus ISAs are assimilated to a broader range of phenomena that include metaphor, irony and other implicatures.

According to Searle, ISAs are speech acts performed indirectly through the performance of other speech acts. Searle's claim of simultaneous performance is supported by speaker's reports of utterances: he observes that " Can you pass the salt? " can be reported by saying "he asked me whether ..."

Searle (1975:65) lists six categories of sentences used for indirect requests, and then (P.72) provides us with four generalizations: a speaker can request indirectly by asking whether, or stating that, a certain felicity condition obtains (e.g. preparatory, propositional content or sincerity conditions ). Searle (1975:73) then provides us with a list of ten steps necessary for inferring the indirect force in " Can you pass the salt?". Here are briefly some of them:(H=hearer)

Step 1: Y has asked me a question as to whether I have the ability to pass the salt. 
Step 2 : I assume that he is cooperating

Step 3 : There is no indication of an interest in my salt-passing ability.

Step 5 : Therefore his utterance is not just a question.

Step 6: A preparatory condition for any directive is $\mathrm{H}$ 's ability to perform the act in question.

Step 9 : He has therefore alluded to the satisfaction of a preparatory condition for a request.

Step 10: Therefore he is probably requesting me to pass the salt.

But Searle points out that the hearer does not go through these inferential steps consciously. They are usually short-circuited. The hearer simply hears it as a request. Searle suggests that this is the main reason why some linguists (e.g. Sadock) are tempted to think that such sentences have an imperative force as part of their meaning or that they are "ambiguous in context ". According to Searle the forms in (1) are conventionally established as standard forms for ISAs. They are conventional ways of requesting, but at the same time they do not have an imperative meaning.

On Sadock's view, the sentences standardly used indirectly have additional literal meaning. Hence the standardized use of such sentences is not indirect, but direct and literal, and their ambiguity lies in their two meanings and two literal uses. Thus the sentences in (1) could be used literally either as questions or as requests. The historical vision behind Sadock's (1974) ambiguity thesis is that sentences such as (1) originally could be used literally as questions, but with the standardization of their indirect use, they came to have another literal meaning: as requests.

The psychological argument for Sadock's view depends on the immediacy of the inference to the indirect force; hence such sentences as (1) need not be consciously disambiguated with regard to force. On this view, the apparent absence of inference can only be explained by assuming the existence of ambiguity. To avoid this argument we have to prove the psychological reality of inference, even though it is not conscious.

Searle undertakes to do this through his concept of illocutionary conventions. These conventions account for the immediacy of inference since they involve mutual belief that certain sorts of utterances count as certain sorts of illocutionary acts. Thus they help to bypass the inference or short -circuit it. As Searle (1975:73) says, the addressee ' simply hears it as a request '. He claims that the additional illocutionary force is not part of the literal meaning of the sentence but is an inference derived via the literal meaning. This is clear from (fact 1) which Searle (1975:67) points out concerning indirect requests through the use of interrogatives: 
(4)

Fact1: The sentences in question do not have an imperative force as part of their meaning. This point is often denied by philosophers and linguists, but very powerful evidence for it is provided by the fact that it is possible without inconsistency to connect the literal utterance of one of these forms with the denial of any imperative intent, e.g:

- I 'm just asking you, Bill: why not eat beans? But in asking you that, I want you to understand that I am not telling you to eat beans, I just want to know your reasons for thinking you ought not to.

Both Sadock and Searle subscribe to LFH, but the first explains ISAs using the notion of idiom and ambiguity whereas the second explains them using the notions of inference and convention.

\section{The Rejection of LFH: A Radical Solution}

A third alternative to the idiom and inference theories is to reject the LFH in principle and argue that sentences do not have literal forces at all. See Levinson (1981) for details of this radical solution to the problem of ISAs. This, in effect, means that there are no ISAs and no problem of ISAs. One consequence of this is that illocutionary force is interpreted purely pragmatically through context, and hence has no direct correlation with sentence form or sense.

Levinson(1983:275) suggests that this radical solution is not simply a way of dealing with the problem of ISAs; it is a general theory of speech act where semantics has only a limited role in assigning meaning to sentence-types and performatives. It is supported by the general observation that the three major sentence-types are rarely used to perform their putative " literal forces ". By contrast, on the theories that subscribe to LFH, almost all utterances should be considered ISAs with the superfluous detour via the literal force.

\section{PART II}

\section{Indirect Speech acts in Traditional Arabic Linguistics}

\section{ISAs and Majaz in Arabic Rhetoric}

The most frequent term Arab scholars use to refer to ISAs is "Afa'al Majazia" (non-literal acts). They distinguish between two kinds of "Majaz" (non-literal use): there is "Majaz mufrad" 
(non-literal use of a single word or expression) and "Majaz murakkab" (non-literal use of a sentence). The first is almost the same concept that is indicated by the term 'metaphor' in western rhetoric. The term "Afa'al Majazia" does not take its meaning from this commonplace concept but from the second one i.e. "Majaz murakkab", which Arab rhetoricians define in terms identical to those we know of ISAs. Thus they speak of "istifham majazi" (non-literal interrogative) and "khabar majazi" (non-literal declarative) and "talab majazi" (non-literal imperative).

We remember that according to Searle an ISA is a speech act performed indirectly through the performance of another speech act. Thus, Searle assumes that the literal force of the utterance is also performed and this question has been an issue and a source of heated debate as we have pointed out above, but more of this later.

The second assumption behind Searle's claim is the literal force hypothesis (LFH) that there is a form-force correlation especially between the three grammatical moods of declarative(indicative), interrogative and imperative on the one hand, and the illocutionary forces or functions associated with them (statement, question and request) on the other. ISAs are the result of a mismatch between the sentence type and the illocutionary function.

Now these ideas were very common among Arab rhetoricians and Usulies (jurisprudents). We select a few samples for illustration. In his encyclopaedic book (Kashaf) Al-Tahanawi ${ }^{2}$ (d.1158H.,1963,vol.1:303) surveys the definition of "majaz murakkab" by previous rhetoricians such as Isfara'ini, Qizwini and Taftazani:

\footnotetext{
.....Majaz murakkab is the use of a sentence for a function other than that for which it was originally instituted, by virtue of an inferential relation and a contextual indicator or clue that blocks the instituted conventional force ... And majaz murakkab does not include one-word majaz. What majaz murakkab really means is a linguistic construction (a sentence) used as such, i.e as a constructed sentence in it's holistic aspect for a function other than that for which it was originally instituted ...... (my emphasis)
}

He, then, mentions Taftazani's comment:

$$
\begin{aligned}
& \text {.... in the same way as individual words were instituted to mean their } \\
& \text { individual senses, sentences were also instituted to mean their sentential } \\
& \text { functions according to sentence-type. For instance, the structural form of a } \\
& \text { sentence such as : "Zaid is standing", is conventionally (originally) instituted } \\
& \text { to function as a statement to assert or predicate the attribute standing of } \\
& \text { Zaid ; however, if that structural form or sentence is used for a function }
\end{aligned}
$$

When referring to Arab scholars' works I will use the usual modern method of referencing but add the ${ }^{r}$ year of death of the scholar at the beginning of the reference. 
other than that for which it was instituted, then there must be some relation between the two meanings...

Al-Khudhari(d.1287H.,1931:79) in his gloss on Risala Samarqandia stresses this version of LFH and says that Taftazani in his (Mutawwal) subscribed to it:

\begin{abstract}
.... He said that it was literally instituted, i.e. literal institution so as to be primary and original ; thus he distinguished it from interpretive institution, which is subsidiary and supplementary, and this is true in the case of non-literal uses as we have explained above. And here we have an explicit declaration that sentence-types are instituted, which is true, but their institution is according to type. For instance, the structural form (or type) "Zaid is standing " is instituted to perform an assertion which predicates the predicate of the subject, as explained in Mutawwal ; (my emphasis)
\end{abstract}

These ideas and more were proposed by Ibn-Al-Shajari (d.542H.,1930,vol.1:277) in his (Amali).

Majaz murakkab, as it was described by some rhetoricians, is not a natural kind, because they extend it to cover cases where the relation or link between what is said and what is meant is one of analogy or resemblance. But many rhetoricians argue that majaz murakkab is a subcategory of "majaz mursal" ("mursal" means free from resemblance).

To sum up, the technical term used by Arab rhetoricians to designate ISAs, namely, " Afa'al Majazia" (non-literal acts), refers to Majaz murakkab, which is a subcategory of "majaz mursal" (non-resemblance majaz) and not to the more frequent and commonplace term of "majaz mushabaha" (resemblance or metaphorical majaz). We should not be misled by this common term, because all the examples they give for "Afa'al Majazia" are ISAs in Searle's terms.

It is interesting to note that, according to Arab rhetoricians, in the case of (majaz) in general and (majaz mursal murakkab) in particular, there has to be a (qarina) i.e.. an inference trigger or a contextual clue to indicate that the literal interpretation is not feasible or, as they put it, مانعـة من ارادة المعنى الحقيقي 'mania min iradat al-mana al-haqiqi' = 'to block the literal force interpretation'. This qarina or trigger can be either (lafdhyia) textual or 
(halyia) i.e. contextual (having to do with the context of situation). There should also be (ilaqa) or a relation between the literal and the intended meaning. Thus they define (majaz mursal murakkab) as any sentence or utterance used for a function other than its conventional or institutional function, because of a relation other than resemblance. This (ilaqa) boils down to the steps of inferring the primary illocutionary act from the secondary illocutionary act, which Searle borrowed from Grice,(see 1 above) .

\section{The Steps of Inferring Indirect Force in (Shuruh Al-Talkhis)}

Now, there is a striking similarity between the inferential steps used by Searle and those used by Arab rhetoricians, especially in the commentaries on Talkhis (Shuruh AlTalkhis).

The use of inferential steps in explaining linguistic comprehension can be traced back to Abdul-Qahir Al-Jurjani (died $471 \mathrm{A.H}$ ) and his disciple Al-Sakkaki, who went as far as claiming that all figures of speech were samples of enthymeme ${ }^{3}$. One quote may suffice to illustrate the type of inference Al-Jurjani was thinking of . In his (Dalail ljaz P.330) he explains how 'Kinayat' (euphemisms ${ }^{4}$ and metonymies) are interpreted:

\footnotetext{
..and if you consider it [euphemism] you will see that it boils down to establishing some meaning through reasoning and inference not through the verbal sense. Can't you see that when you consider an utterance like 'he has a lot of ashes', and understand that it means that he is hospitable and generous, you do not learn that from the words, but by reflecting and reasoning this way: 'It is an utterance usually used for praising, but having a lot of ashes is irrelevant to praise; therefore it is only because they want to imply by "having a lot of ashes" that he has a lot of cooking pots in which food is cooked for guests, because the more food is cooked, the more firewood is burnt; and the more wood is burnt, the more ashes there are ...
}

\footnotetext{
${ }^{3}$ An enthymeme is a deductive conclusion in which one of the parts, either a premiss or the conclusion, is not explicitly stated.

4 There is a mismatch between the Arabic concept of 'Kinaya' and euphemism or metonymy: it does not nearly fit into one or the other. It is more of a euphemism but the reason behind it does not have to be to avoid offence. This indicates that such figures of speech are not natural kinds. See Sperber \& Wilson (1986:243) for other reasons.
} 
This step towards inferential explanation of language was followed by a long series of developments in that direction. Al-Sakkaki went so far as to supplement his famous book (Al-Miftah), which is a linguistic book, with a final chapter on syllogisms and logical deduction. He explicitly argues for a deductive and syllogistic analysis of figures of speech. He illustrates his argument using two metaphors:

5-Her cheek is a rose.

6-Her cheek is an aubergine (egg-plant).

Al-Sakkaki (d.626H.,1937:268) suggests that these metaphors are interpreted via enthymemes where the implicit premises are:

7-Roses are red.

8-Aubergines are black.

the implications being her cheek is red or is black, respectively. He then explains the relationship between rhetoric and logic and the plausibility of supplementing a book on rhetoric with a chapter on logical deduction.

As can be rightly predicted, Al-Sakkaki's next step was to use his analysis in explaining ISAs. After pointing out the form-force correlation (LFH), he says (1937:146) "Whenever it is not possible to interpret these sentence-types literally, new interpretations relevant to context will emerge". He then goes on to survey and explain a range of ISA examples (about forty examples).

According to Sayyid Shereeff Jurjani (d.816H.,1912:135) in his gloss on Taftazani's Mutawal, the issue of explaining the relevance of the indirect illocutionary meaning was avoided by many commentators because of its difficulty. But he himself undertakes that task and achieves it successfully .

However, for lack of space, we select a few illustrative examples from Ibn-Yacoob AlMaghribi's commentary on (Talkhis). He borrows his examples from Sayyid Shereeff but is more systematic and detailed in his analysis. He points out that the interrogative form is often used for purposes other than questioning, thus acquiring a majazi (non- literal) meaning according to its relevance, with the help of an inference trigger in context. He then gives the following example Maghribi(d.1110H.,1924:290):

.A case in point is 'istibta' الاستبطاء i.e. (blaming someone for being late) e.g. your saying to someone whom you called but was late to come: "How many times have I summoned you?". Of course you do 
not intend to ask him about the number of summonses because he does not know it; and it is not relevant to any purpose. Thus the qarina (contextual trigger/clue or indicator) of the addressee being late, which is undesirable, and the question being irrelevant to the [current] purpose, and the addressee being ignorant of the number, indicate that the intended force is to blame for being late. The [inferential] relation is as follows: the question about the number of summonses, which is the literal signification of the utterance, entails or implies ignorance of that number, and that ignorance implies, usually or allegedly, that it is large, and that it cannot be calculated or estimated immediately; and its being large entails the passing of a long period of time between asking and compliance, and that long period entails blaming for being late. Thus it is more like 'majaz mursal' (non-resemblance majaz) and the relation is one of entailment or implication: using what indicates the effect for the cause. (my emphasis).

The above text is rich with implications. Al-Maghribi categorically asserts that what is meant by "majazi" in the case of ISAs is "majaz mursal", and this supports my argument. However he should have described it as "majaz mursal murakkab". Being only "mursal" does not guarantee its being "murakkab", which is the most important thing:i.e. the use of a sentence, not an individual word, as such in its holistic aspect for a function different from its original. It is "mursal" because the relation is not one of resemblance but of cause-and effect in this case, since there is no resemblance between asking about the number of summonses and blaming someone for being late.

Al-Maghribi also points out, though indirectly, that the sentence used for performing an ISA retains its literal sense, but we shall deal with this issue in a separate section.

Now, the aspect which is more significant to us in the above text is the inferential steps which Maghribi suggests the addressee follows in order to reach the indirect illocutionary force. We can arrange and number these steps after Searle in (1) above to make the comparison easier:

(9)-

a. The speaker has said : 'How many times have I summoned you?', which is an interrogative sentence ( a fact about the conversation).

b. The literal signification of that interrogative sentence is a request to know the number of summonses (LFH, a linguistic fact).

c. The question about the number of summonses is irrelevant to the present purpose (factual background information + principles of conversational 
cooperation, especially, the relevance maxim, which Maghribi assumes as given)

d. Furthermore, it is not the case that the speaker intends to ask the addressee about that number because the ${ }^{5}$ latter does not know it (inference from the previous steps)

e. The speaker has called the addressee, but he was late to come. (a fact about the conversation).

f. The question about the number of summonses, which is the literal signification of the utterance, entails or implies ignorance of that number (the preparatory condition / speech-act theory).

g. That ignorance, usually or allegedly, implies that the number is large and that it cannot be calculated or estimated immediately. (inference from the previous step).

h. Its being large entails the passing of a long period of time between asking and compliance (inference from the previous step).

i. That long period entails that the addressee was late and that he is blamed for being late. (inference from the last two steps)

j. Thus the speaker in saying "How many times have I summoned you?" intends not asking, but blaming for being late (majaz mursal, the relation is one of entailment: using the effect to indicate the cause).

It goes without saying that the essential properties that the inference theories of ISAs share such as the LFH, the inference trigger, etc. (Levinson 1983:270), are all there in the Maghribi text.

Another example is the use of the interrogative for threatening, Maghribi(d.1110H.,1924:293)

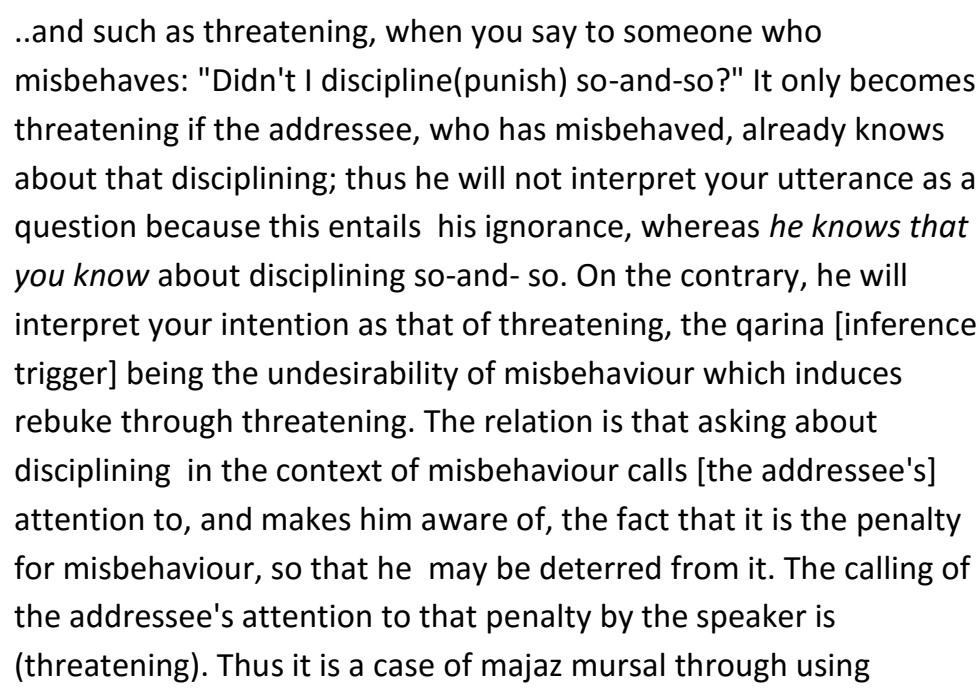

${ }^{5}$ According to Al-Subki, another commentator on 'Shuruh', it is the speaker who does not know the answer, which sounds more plausible. See (Aroos, p.304). 
something for what relates to it by the relation of entailment. (my

emphasis)

The above example indicates an awareness of the role of common or mutual knowledge in deciding the illocutionary force of an ISA, or at least that it is an ISA.

The last examples we quote from him are those of interrogatives used for irony and contempt Maghribi (d.1110H.,1924:303) :

and such as irony, e.g. in the holy Quran the unbelievers are quoted as saying to prophet Shu'aib ((peace be upon prophet Muhammed and upon him)):"O Shu'aib! Is it thy prayer that commands thee that we should forsake what our forefathers worshipped?", for the intention is not to ask whether the prayer really commands the above- mentioned, which is obviously false, but their intention(God's curses be upon them) is to be sarcastic and mock Shu'aib in his prayer; it is as if they said to him: "You have no special privilege that authorizes you to command us except this prayer which you say regularly, and neither it nor you are anything." Hence it has become as though one would suspect that the prayer itself commanded the prophet; and attributing the command to the prayer is a majaz of predication: .... the relevance or relation [between what is said and what is meant] is that asking about the prayer being the source of the command is compatible with the addressee's belief that it is the source of the command; and that belief entails ridiculing the believer since a prayer cannot command or prohibit. Thus it is an instance of "majaz mursal" and the relation is one of entailment.

and such as contempt or scorn, e.g. saying "who is that ?" referring to someone you know, the intention being to scorn him. The relation is that it is usual of the contemptible to be unknown because nobody pays attention to him; hence the question about his identity. The relation is one of entailment...

The explanation of irony which Maghribi gives above is, in many respects, closer to the Sperber \& Wilson $(1986,1995)$ approach than to the traditional one. Sperber \& Wilson conceive of ironical utterances as cases of echoic interpretation. By representing someone's utterance or opinions in a certain way, the speaker expresses his own attitude to the thought echoed. Ironical utterances are echoic, and are primarily designed to ridicule the opinion echoed. In the Maghribi example above, the unbelievers are echoing an opinion, which is absurdly incorrect, and attributing it to prophet Shu'aib. Their attitude to the opinion echoed is one of dissociation and rejection, and this is what makes their utterance ironical. 
This example falls outside the scope of the classical definition of irony as saying one thing and meaning the opposite. What the unbelievers mean is not that it was not Shu'aib's prayer that commands him.. etc. According to Sperber \& Wilson 1986 what makes such utterances ironical is "an echoic element and an associated attitude of mockery and rejection."

\section{Does a Sentence Lose or Retain its Literal Meaning When Used as an ISA ?}

We have noticed that ISAs are based on LFH and the mismatch between form and force, and that the two major approaches to explain this phenomenon are the idiom(or ambiguity) theory and the inference (or conventionality) theory. The first one claims that sentences standardly used to perform ISAs have additional literal meanings and therefore they are ambiguous. According to Sadock(1974), ISAs are idioms that resist paraphrase.

The second approach, or at least Searle's version, claims that it is not viable to multiply meanings unnecessarily; questions used for requesting or suggesting do function as questions in addition to their indirect use; and their indirect force is not idiomatic. Hence it is a question of a different use, not a different literal meaning. It is a question of illocutionary conventions or the knowledge that the utterance of a sentence of a certain form literally used to perform one illocutionary act counts as the performance of another (Bach \& Harnish 1979:184).

We have already described in some detail the dispute between Searle and Generative Semanticists like Sadock. We have pointed out that Searle's answer to the question of this section is that the sentence functioning as an ISA retains its literal meaning in addition to the indirect force. This is obvious from(fact 1 ) which we quoted above in (4)

Now the question is: Did Arab linguists know these issues and concepts? The answer is: yes, and they knew both approaches: the inferential and the idiomatic.

A large number of them, especially rhetoricians and jurisprudents, argued that the literal force of the utterance rests as it is and the indirect force is an additional inferential meaning. This is clear in the work of rhetoricians such as Maghribi and Subki etc. in their commentaries and glosses (Shuruh Talkhis) where, as we have noticed in the last section, the literal force interpretation figures as a first step in a long series of inferential steps that lead to the indirect force. Thus the question about the number of summonses is a first step that leads in the end to the indirect force, blaming the addressee for being late. The same applies to all the examples we quoted above : the interrogative force being a first step in the inferential process of comprehension. In this, Arab rhetoricians are like Searle who argued 
that in an ISA, the speaker performs an illocutionary act through the performance of another and in addition to it.

However, other Arab linguists, especially grammarians, adopted an approach similar to that of the Generative Semanticists, who argued that in ISAs there is a change in the literal meaning. Sometimes they even went further than Generative semanticists and talked about ISAs as if they were due to changes in the meanings of certain words (the question words in the case of ISAs using the interrogative form). Here are some examples from the Holy Quran:

10- How many generations before them we destroyed (verse 128, ch.20).

11- And who does more wrong than he who invents a lie against God? (verse69. ch.29).

According to Al-Jalalain (Jalal and Jalal) (d.761,911H.,undated), the change of the literal meaning in the above verses is due to a change in the literal meaning of the question words. Thus the question words "how many" in (10) have literally come to mean "many" and the utterance as a whole becomes an assertive. Arab grammarians call it "assertive (how many)". Hence the meaning of the verse would be:

12- Many generations before them we destroyed.

This practically means that we have more than one (how many).So, there is, according to this view, an ambiguity in the literal sense of the words.

This is exactly the opposite of the explanation of rhetoricians of "How many times have I summoned you?" in (Shuruh Talkhis) where they argue that the meanings of words rest as they are and they only acquire the indirect force as an additional meaning through context.

Al-Jalalain also think that the literal meaning of "who" in (11) above has changed into "Nobody" . Thus, the meaning of the verse would be:

13- Nobody does more wrong than he who invents a lie against God.

This approach, as we have mentioned above, is inadequate and leads to the proliferation of lexical meanings unnecessarily. Moreover its explanatory power is limited: it can explain some cases but is not generalisable to the others. It is adopted mostly by grammarians e.g, 
Mubarrid, Harrawi and Maliqi. But every now and then we find some exceptions like IbnJinni(d.392H.,1954,vol.3:263) in his (Khasais), where under the rubric of "non-literal interpretation" he argues that when an interrogative utterance is used to express an indirect meaning (majaz), it retains its interrogative meaning "as if the question was used here to be followed by its answer (yes); and if that is the case, it will be used then for eliciting a confession and consequently for advice and reprimand..".

In this, Ibn-Jinni was anticipating the kind of explanation that rhetoricians were to offer in (Shuruh Talkis).

Ibn Al-Shajari(d.542H.1930,vol.1:277) is another exception in his (Amali); he adopts an explanation similar to that of Searle: "..and I have shown you that most utterances or sentencetypes have the potential of meaning something different from that for which they were instituted, but that meaning potential does not mean that they lose their original meaning." However, sometimes, he sounds more like an advocate of the ambiguity thesis and this is obvious form the following quote (d.542H.,1930 vol.1, 268) :

\footnotetext{
...and the interrogative sometimes is used for offering or inviting e.g. when you say: "Won't you pop in? Won't you have something to eat?" An offer is more of a request than a question. But some [scholars] subsumed it under question because its form is interrogative. However, as I have shown you, not every utterance that is interrogative in form is a literal question. If offers were questions, the addressee would not have been obliged to say 'thank you' to the speaker.
}

\section{Shuruh Talkhis and the Inferential Approach}

Among the rhetoricians of Shuruh Talkhis Baha Subki (719-773) was distinguished for his deep and lucid treatment of the above question. In his (Aroos Afrah), after illustrating the use of interrogatives for Indirect illocutionary forces, Subki (d.773H.,1924:306) explicitly raises the same question that Searle and Sadock dealt with:

Should we say that the interrogative meaning is still there [in the utterance] and some other meaning was added to it, or that it lost its interrogative meaning entirely? The answer is disputable. But evidence supports the first alternative........ 
This is also supported by the fact that when you blame someone for being late by saying "How many times have I summoned you? " the inference is that the number of summonses is so large that I do not know it; therefore I request to know that number. And usually one asks about the number of what one did if what one did was repeated so many times that one does not know how many; and inquiring about the number implies blaming for being late.

Subki's answer to the question is also close to that of Searle and his inferential approach, namely that the secondary act of meaning (the literal or direct one) is there in addition to the primary one (the majazi or indirect). This conclusion is, of course generalizable and it applies to the majority of ISAs.

However, Al-Zarkashi (d.745H.,1957,vol.2:347), another rhetorician and commentator, provides us with more alternative answers to the question, and he leaves the door open for explanations

\begin{abstract}
concerning these types of non-literal questions, should we say that the interrogative meaning is still there and some other meaning was added to it, or that it lost its interrogative meaning entirely? There should be no absolute decisive answer, for there are cases where it is lost, others where it is maintained, and yet others that are open for many different interpretations, all being known through inference and reflection.....Both answers are there in the works of grammarians and rhetoricians.
\end{abstract}

Al-Zarkashi mentions both the grammatical and the rhetorical perspectives, and allows enough latitude for reflection and inference, for he does not believe in an absolute answer to this question.

Subki sheds a new light on this issue when he analyses 'taqrir', which is an illocutionary act similar to that of a leading question with the intention of eliciting a confession from the addressee (or from the audience, as Subki interestingly points out). This analysis is complicated by a theological constraint when the speaker is God (Allah): is it possible that God the Omniscient asks questions seeking information? The answer of the majority of commentators was that the interrogative force disappears when the speaker is God: His questions are all non-literal. However, Subki argues that, in the case of "taqrir" the interrogative force does not disappear but the question is asked for the benefit of a third party who is the real target of the question. It is more like what Jenny Thomas (undated) calls a "complex illocutionary act". Subki (d.773H.,1924:307) points out: 
..And here is a fine distinction, namely that a question is a request for information, but is the target of this requested information the speaker himself or whoever is in need of that information? Thus if somebody, who knows that Zaid did stand up, said to Amr, in the presence of Bakr, who does not know that Zaid stood up: "Did Zaid stand up?", then he would be interpreted as informing the real addressee, i.e. Bakr, of that piece of information. If what I say is right, then there is nothing wrong with the speaker asking about what he already knows....

Thus you see that the interrogative in 'taqrir' is still there in its literal sense, and that God's question to Jesus Christ in the Quran "Oh Jesus, son of Mary! Didst thou say unto men: worship me and my mother as two gods besides Allah?" is literal, for He uses it to elicit an answer which shows Christians that their claim is untrue and that Jesus did not say that.

The interesting thing here is Subki's vision that the real target or addressee can vary according to context: you can ask about what you already know to call a third party's attention to the answer. And this is one instance of what Arab rhetoricians call تجاهل العارف"Tajahul Al-Arif" (the knower pretending ignorance). He, then (p.308), goes on to survey many examples of questions used as ISA for additional illocutionary forces, and summarizes his argument:

..to put it briefly, the interrogative meaning is retained in addition to another meaning with the help of contextual or cotextual clues..

But it seems as if the controversy over this question were only verbal; rhetoricians whom Subki criticizes for labelling ISAs as " majaz" (non-literal uses) do not deny that the interrogative meaning is retained since, as we have mentioned above, literal interrogative meaning figures in their analyses as the first step in inferring the indirect force.

This conclusion anticipates the claim of linguists like Searle and Dascal that the indirect illocutionary force or implicature is not a new sentence meaning but part of speaker's additional meaning. As Dascal (1983:34) puts it in a different context:

When mother yells supper is served, thereby meaning that father is to stop playing the clarinet and Jocelyn is to wash her hands and come to table, we cannot say that, though her words do not timelessly mean 'stop playing the clarinet' this is what they mean on this occasion.

This is what she means by uttering them on this occasion. 
Although Dascal is speaking in a different context, what he says leads to the same conclusion: that the indirect force or implicature is not part of the semantic meaning of the sentence but of speaker's meaning.

\section{The Interaction Between Form and Force: Are ISAs Cases of Ambiguity or "Majaz" or is LFH to be Abandoned?}

In this section we are going to deal with the use of the imperative for direct and indirect illocutionary acts. The choice of the imperative is warranted by the amount of what was written on it in the Usülies' literature; and this is explained by the fact that Islamic law which is derived from the Quran and the prophetic Tradition is mostly in the form of directives.

There was much heated debate among Muslim linguists and Usülies concerning whether directives have a certain linguistic form or mood, and whether the imperative form "Do!" is restricted to directives. This question is closely related to ISAs and the form-force correlation.

We shall see that some scholars argue that there is a direct form-force correlation between the imperative and Directives; others argue that the imperative is 'mushtarak' مشترك (i.e, ambiguous or polysemous): it has more than one force built into it; others claim that the other meanings or forces are cases of majaz مجاز (ISAs), not 'mushtarak', i.e. the imperative is used for other forces; and there are yet others who solve the problem by "Waqf"وقف (rejecting the LFH ). Waqifies, as they are called, reject any a priori assignment of meaning to words.

These are extreme 'Waqifies' وو اقفية; however, there are moderate Waqifies, like Ghazzali, who allow room for the assignment of very general and broad meaning to forms.

Waqifies are the first radical pragmatists or contextualists; their slogan is to stop and think of the context before making a judgment (Waqf literally means 'stoppage').

The above-mentioned different views about the LFH and the status of nonliteral illocutionary force are very close to the views of the proponents of the ambiguity theory, the inference theory and the rejection of LFH in modern pragmatics.

But first let us survey these different perspectives. Again for lack of space, we have to be selective.

Sayfuddin Amidi (d.631H.,1983:205) points out: 
There was a dispute about human speech : Is there a special linguistic form exclusively indicating command (order)? Abu Hassan Ashari and his followers said there isn't, while other scholars said there is. Al-Juwaini and Ghazzali said: to attribute the above view to Ashari is a mistake, since "I order you to ..." and "You are ordered to.." are special forms indisputably associated with command. In fact the dispute is over the imperative "Do!" : whether it is restricted to command or not, since it is used to express many different meanings, as we shall see.

What Amidi is referring to above is obviously the dispute over LFH and the form-force correlation, which is a familiar issue in modern speech act theory. It is also obvious that Ashari represents an extreme rejection of LFH and the consequences of that rejection.

However, we shall see that some of his followers, like Ghazzali, are moderate and concede that there is at least 'qadr mushtarak' (common core) of meaning that is always associated with the form.

Ghazzali(d.505H.,1904,vol.1:417) also points out that the dispute is not over explicit performatives but over implicit ones. Let us listen to him surveying different views :

\footnotetext{
...the dispute is rather over utterances like "Do this or that". Does such an utterance mean command regardless of context? for it is used to express different meanings such as ...... These are fifteen different intentions for uttering the imperative form, and seven for uttering the negative imperative; therefore we should investigate what the original meaning is, and what the majaz (indirect intention) is. Some people say that the form is ambiguous (or polysemous) covering all these fifteen meanings like the words ['eye', 'head' ]6. Others say that the form indicates the minimum common core which is permission; other people say it indicates preference and can indicate obligation with the help of context; and yet others say it indicates only
}

${ }^{6}$ These words are the English equivalents of Gazzalie's original ones: the aim is to exemplify polysemy as in the use of parts of the body, e g., head of a state, eye of a needle, mouth of a bottle and hand of a clock ,etc. Polysemy is akin to ambiguity and homonymy but is unlike them in that its distinct meanings are related. 
obligation unless there is 'Qarina' (contextual clue) indicating

other meanings.

Then Ghazzali undertakes to undermine the arguments of the proponents of the ambiguity or polysemy theory and any argument for an apriori interpretation depending on literal meaning regardless of context. He (Mustasfa, vol.1 p.420-430) adopts a pragmatic view in which one should "stop" and look into the context every time one comes across the linguistic form, in order to see the actual meaning or force because the latter is not absolute or fixed.

Gazzali (d.505H.,1904,vol.1:420-430) elaborates on these issues but for lack of space we summarize his view: he argues that the imperative mood does mean some common core of requestive force; it is easy to tell the difference in meaning between the imperative and the negative imperative (prohibitive): they cannot both be in the same form although the imperative can be used for a prohibitive force, in the same way as it is easy to tell the difference between the past, present and future tenses, although the past tense can be used to refer to the present with the help of contextual clues (qarina).

Thus, according to Ghazzali, the imperative is not ambiguous or polysemous covering the meanings of threatening, advise, permission etc. These are additional meanings inferred from context: the imperative is coloured with them through use in context, what Gazzali rejects is some other usulie's claims that the imperative form or utterance is semantically ambiguous and regardless of context. He also rejects the claim that one or the other of its alleged meanings outweighs the others and is considered by this or that scholar as the original literal meaning, a claim which is counter-intuitive according to Ghazzali.

An interesting topic for research may be a comparison between the 'waqf' of Ashari who is extremist and refuses to concede any literal sense (rejection of the LFH) and the 'waqf' of his disciple Ghazzli, who is moderate in his rejection of LFH and concedes some 'qadr mushtarak' or common core. I think that such thinkers, and they are not unique in Islamic culture, were really the forerunners of some of the ideas that we come across in the works of modern pragmaticists.

\section{Conclusions and Recommendations}


Using many quotations from the books of Arab and Muslim rhetoricians and jurisprudents such as Taftazani, Jurjani, Sakakki, Maghribi and Subki and many others, the researcher finds supportive evidence for his main hypothesis that Arab linguists were well acquainted with ISAs centuries before their western counterparts. Except for some differences in the technical terminologies, the quotations show that Arab linguists were familiar with almost the same notions and were involved in very similar debates and controversies over the right approach to explain the phenomena: the ambiguity approach, the inferential approach and even the radical pragmatic approach are all there. Searle's inferential steps and the controversy over the question: " Does an utterance lose or retain its literal force?" figure prominently in the quotations from Arab linguists. Arab linguists used terms such as "majaz murakkab" and "afaal majazia" to refer to what is known as indirect speech acts in modern pragmatics. Special reference is made to questions and directives as samples of ISAs.

The above conclusions are hardly surprising if we bear in mind that Arabic culture is often described as " a linguistic culture". It is recommended that other linguistic phenomena should be investigated with the same aim of finding out whether they were familiar to Arab linguists.

\section{ARABIC REFERENCES}

Amidi, S.D. (1983) Al-Ihkam. Beirut: Al-Ilmiya Press.

Ghazzali, A. H. (1904) Al-Mustasfa. Bulaq: Ameeria Press.

Ibn-Al-Shajari,A.S. (1930) Amali Shajaria. Haidar Abad: Al-Maarif Al-Othmania.

Ibn-Jinni, A. F. (1954) Al-Khasais. Beirut : Al-Huda Press.

Jalal \& Jalal (Jalalain) (undated) Tafseer Al-Jalalain. Beirut : Al Shabia Press.

Jurjani, A. (1961) Dalail ljaz. Cairo: Cairo Press.

Jurjani, S.S. (1912) Gloss on Mutawal. Istanbul: Kamil Press.

Khudari, M.(1931) Gloss on Risala Samarqandia. Cairo: Al-Azharia Press.

Maghribi, I. Y. (1924) Mawahib Al-Fattah. Cairo: Al-Saada Press.

Sadock, J.M., (1974). Towards a Linguistic Theory of Speech Acts. New York: Academic Press. 
Sakkaki, A. Y. (1937) Miftah Al-Uloom. Cairo: Al-Halabi Press.

Subki, B. (1924) Aroos Al-Afrah. Cairo: Al-Saada Press.

Taftazani, S .D., (1912) Mutawal. Istanbul: Kamil Press.

Tahanawi,M.A. (1963) Kashaf Istilahat Al-Funoon. Cairo: Al-Nahda Press.

Zarkashi, M. A. (1957) Al-Burhan. Beirut: Al-Ihia Press.

\section{OTHER REFERECES}

Austin, J.L. (1962) How to Do Things with Words. Oxford: Clarendon Press.

Bach, K., and Harnish, R.M. (1979) Linguistic Communication and Speech Acts.. Cambridge, Mass: MIT Press

Dascal, M. (1983) Pragmatics and the Philosophy of Mind. Amsterdam: John Benjamins.

Grice, H.P. (1975) Logic and Conversation. In Cole and Morgan (eds) Syntax \&

Semantics.vol.3, New York Academic Press.

Leech, J.N. (1983) Principles of Pragmatics. New York : Longman.

Levinson, S.C. (1981) The Essential Inadequacies of Speech Act Models of Dialogue. In Parret, H. (ed.) (1981) Possibilities and Limitations of Pragmatics. Amsterdam :John Benjamins.

Levinson, S.C. (1983) Prgmatics. Cambridge: CUP.

Searle, J.R. (1975). Indirect Speech Acts. In Cole and Morgan(eds) Syntax \& Semantics.vol.3, New York Academic Press.

Sperber, D. and Wilson, D. (1986) Relevance. Oxford: Blackwell.

Thomas, J. (undated) Complex Illocutionary acts. Lancaster Papers in Linguistics. Lancaster University. 


\section{APPENDIX : THE ORIGINAL ARABIC TEXTS QUOTED IN TRANSLATION}

(text No.1)

المجاز المركب هو المركب المستعمل في غير ما وضع له لعلاقة مع قرينة مانعة عن إرادة الموضوع له .. ولا يشمل المجاز ما تجوز في احد

الألفاظ فيه . فالمراد أن المجاز المركب هو اللفظ المركب المستعمل من حيث هوة مركب أي بهيئته التركيبية وصورته المجموعية في غير ما وضع له ....

(text No.2)

أن الواضع كما وضع المفردات لمعانيها بحسب الثخص، كذلك وضع المركبات لمعانيها التركيبية بحسب النوع. مثلاً هيئة التركيب في نحو: ((زيد قائم))، موضوعة للإخبار بإثبات القيام لزيد، فإذا استعمل ذلك المركب في غير ماوضع له، فلابد حينئذ من العلاقة بين المعنيين..

(text No.3)

... قوله ((وضع له حقيقة أي وضعاً حقيقياً بأن يكون أولياً أصلياً، واحترز به عن الوضع التأويلي، وهو الوضع الثانوي التبعي لأنه ثابت للمجاز فلا يصح نفيه. وقد تقدم شرح ذلك. وفي هذا تصريح بأن المركبات موضوعة. و هو التحقيق، لكن وضعها نوعي. مثلاً هيئة المركب في نحو: ((زيد قائم)) موضوعة وضعاً تحقيقياً للإخبار بثبوت المسند للمسند إليه، كما في المطول .

(text No.4)

و إذا نظرت إليها [أي الكناية] وجدت حقيقتها ومحصول أمر ها أنها إثبات لمعنى أنت نعرف ذلك المعنى من طريق المعقول دون طريق اللفظ. ألا ترى أنك لما نظرت الى قولهم (هو كثير رماد القدر)، وعرفت منه أنهم أرادو ا أنه كثير القرى والضيافة، لم تعرف ذلك من اللفظ ولكنك مهرك

عرفته بأن رجعت إلى نفسك فقلتَ: إنه كلام جاء عنهم في المدح، ولا معنى للمدح بكثرة الرماد، فليس إلا أنهم أر ادو ا أن يدلّوا بكثرة الرمادا على أنه تنصب له القدور الكثيرة ويطبخ فيها للقرى وللضيافة. وذلك أنه إذا كثر الطبخ في القدور كثر إحر اق الحطب تحتها. و إذا كثر إحراق الحطب كثر الرماد لامحالة.

(text No.5)

وذلك ((كالاستبطاء نحو)) قولك لمخاطب دعوته فأبطأ في الجواب ((كم دعوتلك؟))، فليس المر اد استفهامه عن عدد الدعوة لجهله بها. ولايتعلق بها غرض، فقرينة الإبطاء واستثقاله، مع عدم تعلق الغرض بالاستفهام ومع جهل المخاطب بالعدد، دالة على قصد الإستبطاء. والعلافة: أن السؤال عن عدد الدعوة، الذي هو مدلول اللفظ، ببتلزم الجهل بذلك العدد، والجهل به ببتلزم كثرته عادةً أو ادعاءً، وأنه لايحصره الإدراك من أول و هلة. وكثرته تستلزم بعد زمن الإجابة عن زمن السؤال، والبعد ببتلزم الاستبطاء. فهو كالمجاز المرسل لعلاقة اللزوم من استعمال الدال على الملزوم في اللازم.

(text No.6)

$$
\text { ((وكالو عيد كقو للك لمن يسيء الأدب)) معك: ((ألم أؤدب فلاناً))) (^). و إنما يكون و عيداً ((إذا علم)) المخاطب المسيء للأدب ((ذلك)) }
$$
التأديب، فلا يحمل كلامك على الاستفهام لأنه يستدعي الجهل، وهو عالم أنك عالم بتأديب فلان، بل يحمله على مقصودك من الوعيد بقرينة كر اهية الإساءة المقتضية للزجر بالو عيد. و العلاقة كون الاستفهام عن شأن الأدب في الإساءة مشعراً ومنبهاً على أنه جزاء الإساءة لينزجر عنها، و التنبيه على ذلك الجزاء من المتكلم وعيد. فهو مجاز مرسل من استعمال اسم الملاِبس فيما يلابسه باللزوم في الجملة. 
(text No.7)

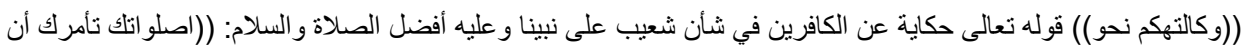

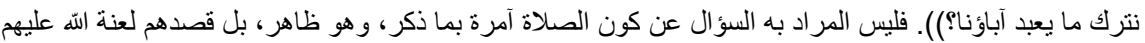

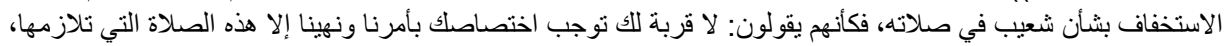

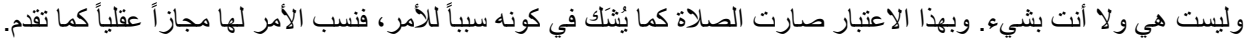

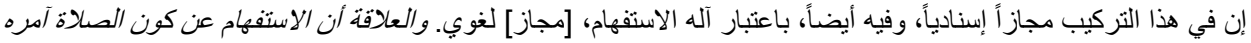

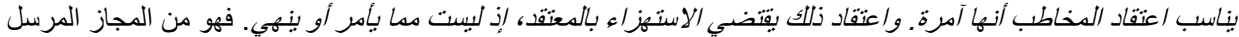

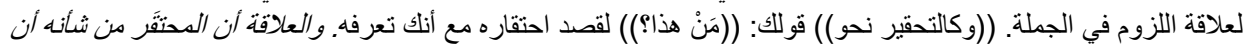

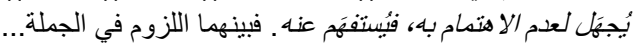

(text No.8)

ويكون [الاستفهام] عرضاً كقو للك (ألا تنزل عندنا؟ ألا تنال من طعامنا؟). والعرض بأن يكون طلباً أولى من أن يكون استفهاماً.

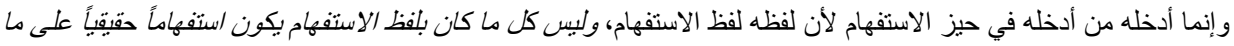

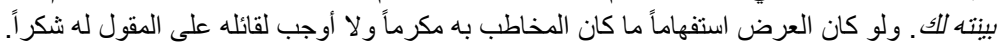

(text No.9)

وهل نقول أن معنى الاستفهام فيه موجود وانضمّّ إليه معنى آخر أو تجرَّ من الاستفهام بالكلية؟ محل نظر . والذي يظهر الأول...

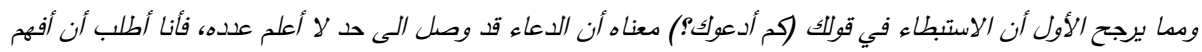
عده. والعادة تقضي بأن الشخص إنما يستغهر عن عدد ما صدر منه إذا كثر فلم بعلمه. وفي طلب فهم عدده ما يشعر بالاستبطاء..

(text No.10)

هذه الأنواع من خروج الاستفهام عن حقيقته في النفي، هل تقول: إن معنى الاستقهام فيه موجود، وانضم إليه معنى آخر ؟ أو تجرد

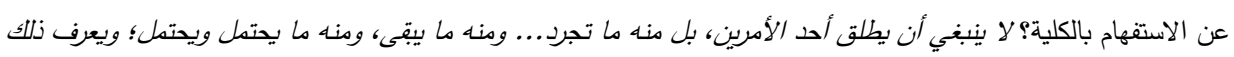
بالتأمل ... وفي كلام النحاة والبيانيين، كلٌّ من القولين، وقد سبق الإشارة إليه.

(text No.11)

وأقدم عليه دقيقة وهي أن الاستفهام طلب الفهم، ولكن طلب فهم المستفهم أو طلب وقوع فهم لمن لم يفهم كائناً من كان. فإذا قال من يعلم قيام زيد لعمرو بحضور بكر الذي لايعلم قيامه: (هل قام زيد؟)، فقد طلب من المخاطب الفهم، أعني فهم بكر ل... وبهذا

انجلى للك أن الاستفهام التقريري بهذا المعنى حقيقة، وأن قوله تعالى ((أنت قلت للناس اتخذوني وأمي إلهين من دون الله؟)) حقيقة. فإنه طلب به أن يقر بذلك في ذلك المشه العظيم تكذيباً للنصارى وتحصيلاً لفهمه أنه لم يقل ذلك....

(text No.12)

فحاصله تكمل المحافظة على معنى الاستفهام مع معنى آخر بمعاونة القرائن اللفظية أو الحالية.

(text No.13)

وقد اختلف القائلون بكلام النفس: هل للأمر صيغة تخصده وتدل عليه دون غيره في اللغة أم لا؟ فذهب الثيخ أبو الحسن

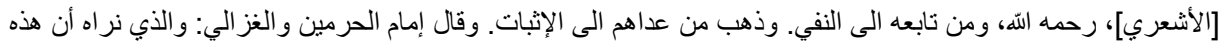

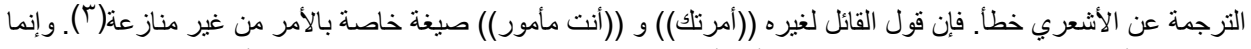

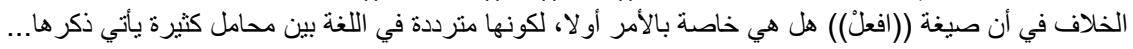

(text No.14)

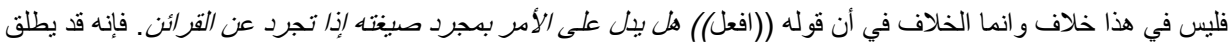

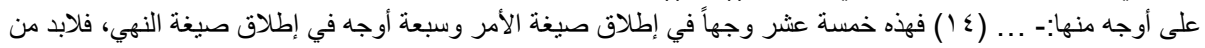

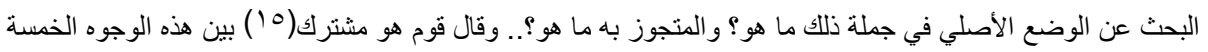


عشر كلفظ العين و القرء. وقال قوم: يدل على أقل الدرجات وهو الإباحة. وقال قوم هو للندب ويحمل على الوجوب بزيادة قرينة

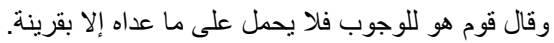

